\title{
Futures Trading in Agricultural \\ Commodities: Effects of the Ban on Selected Commodities in India
}

\author{
Cledwyn Primus Savio Fernandez*
}

\section{Abstract}

The commodity market is one of the emerging markets in today's economy. Given that inflation is increasing alarmingly and the emergence of risk in all activities, the commodity market has a phenomenal contribution to the overall economy of India. The following paper - Futures Trading in Agricultural Commodities: Effects of the ban on selected commodities in India shall focus on the impact of hedging (risk management) and price discovery, which are two major aspects under the agricultural commodity market. Secondary data from two main sources namely the Multi Commodity Exchange Market and National Commodity Derivatives Exchange were used for analysis. The ban on futures trading under agricultural commodities that was implemented by the Government of India shall be dealt with specifically taking seven commodities - Wheat, Rice, Sugar, Chickpea, Potato, Rubber and Guar Seeds. The common element between all these commodities is that they were all banned from futures trading at some point of time or the other. An analysis using econometric and statistical tools shall be performed to check whether there exists any sort of relationship between the ban and the prevailing inflation in the economy and also the correlation between the prices before and after ban. This is purely an explanatory study wherein the strategies for buyers and sellers in the futures market will also be discussed.

* II MA-Economics, Christ University, Bangalore, India; cledwyn91fernandez@gmail.com 
Keywords: Hedging, ban, futures trading, inflation

\section{Introduction}

One of the important sectors of the Indian economy influencing overall economic growth is Agriculture. It helps in determining the growth and stability of the economy. Around $70 \%$ of the population still relies on agriculture ${ }^{1}$ for not only employment but also livelihood and other necessities. In the world, India ranks second when it comes to farm output ${ }^{2}$. Demographically, agriculture is one of the biggest sectors and it plays a very important role in the economy. Agriculture has a big role to play when it comes to the overall socioeconomic factor of India.

In the 11 $11^{\text {th }}$ Five Year Plan (2007-12), the agricultural sector witnessed an average growth rate of 3.6 percent in the gross domestic product of agriculture and other allied sectors. The projected percent growth remains to be $4 \%$ in the next five year plan (12 $2^{\text {th }}$ Five Year Plan). The Government of India has taken a step forward to help the agricultural sector by allowing $100 \%$ Foreign Direct Investment in the agricultural sector for the development of seeds and warehousing. In the $12^{\text {th }}$ Five Year Plan, the Government of India has decided to increase the share of expenditure on Research and Development ${ }^{3}$.

Against this background and keeping in mind the rising agricultural sector, this paper tries to analyze the agricultural commodities futures market. The agricultural commodities futures market are market based instruments for managing risks as well as helping in the orderly establishment of agricultural markets ${ }^{4}$. The main function of the futures market is to help in hedging commodity price risks. The futures market provides a platform to provide supply and demand side conditions that will thereby help in price discovery.

\footnotetext{
${ }^{1}$ www.agriinfo.in (My Agriculture Information Bank)

2 http://www.indiamart.com/knowindia-group/agriculture-inindia.html, Agriculture in India.

3 Planning Commission Report - Five Year Plans (Agricultural Sector)

4 National Bank for Agricultural and Rural Development Website: Agricultural Commodity Futures Market.
}

62 
Given the long history of futures trading in the Indian economy, the sector still remained underdeveloped in major parts because of the simple fact that there was an adequate amount of government intervention in the commodity market mainly to control price. The state still gives the power to control and supply the resources and take charge of the market. Free trade is restricted in most of the items which come under the Essential Commodities Act of 1955 . However since 2003, the Government of India had removed all restrictions under the commodity exchange.

Presently futures trading is being carried out in 81 commodities by around 25 commodity exchange markets. In the year 2003, the National Multi Commodity Exchange status had been accorded to four commodity exchanges namely - National Multi Commodity Exchange, Ahmedabad, Multi Commodity Exchange - Mumbai, National Commodity Derivatives Exchange - Mumbai and the National Board of Trade - Indore. In the year 1952, the Forwards Market Commission was established under the Forwards Contracts (Regulation) Act. The main function was to regulate commodity derivatives trading analogous to the way SEBI regulates the stock market. It was then that NABARD came up as a national level institute to foster spot and futures market trading. NABARD has partnered with the two national commodity exchanges namely MCX and NCDEX and together they work to achieve the objective of establishing an efficient agricultural market in India.

\section{Review of Literature}

The present paper on Futures Trading in Agricultural Commodity Markets gives us an insight on how volatile the emerging future market is. Emerging futures markets are generally known to have unique characteristics. Bakaert and Harvey (1997) stated that emerging futures market is characterized by thin trading and low liquidity. However, Tomek (1980) and Carter (1989) argued that emerging markets are characterized by high price variability and poor information processing. The debate whether or not the futures market stabilizes or de-stabilizes the spot market has been an

${ }^{5}$ One Country, one Market: A MYTH (Report by Kritika Narula, Centre for Civil Society) 
important topic of discussion. One set of views (Cox, 1979; Figlewski, 1981; Clifton, 1985; McCarthy and Najand, 1993; Chatrath et al., 1996) argued that the futures trading market does destabilize the spot market, hence making them more volatile. Another set of economist having a divergent view (Danthine, 1978; Kyle's, 1985; and Froot and Perold, 1991). There has been a lot of arguments put forward that opening the futures market for agricultural commodities lead to inflation and hence banning of futures trading is the optimal solution. This was what the Government of India felt right and thus carried forward and implemented it by banning certain commodities during the year 2007-2008.

The relationship between spot and futures market has also been studied by various economists. Bekiros and Diks (2007) studied the relationship between the spot and futures price in the crude oil market using co-integration and linear causality. A similar study was performed by Garbade and Silber (1983) that focused on a model to examine the price discovery role of futures prices and the arbitrage of price change in spot and futures market of all commodities. A little different from the general studies on commodities, Silvapulle and Moosa (1999) argued that the main function of the futures market remains to be price discovery. In a recent study, Mukherjee (2011) conducted a generalized study on the impact of futures trading on Indian agricultural market and also suggested policy measures to strengthen the market structure. Commodity markets should not be confused with stock markets as they have a different market structure with different rules and regulations. This aspect was studied by Pavaskar (2004). There has been a report by Sen and Paul (2010) which clearly refuted the fact that the futures market helps in price discovery and curbing the volatility of the spot market.

Coming to the ban on futures trading in the commodity market, the topic has been an old one and this is proved by the fact that commodities keep entering and leaving the commodity market as governed by the government. Sharma (2009) studied the effect of the ban of futures trading on agricultural commodities with a specific study on wheat and maize to see whether trading actually caused volatility in the spot market. He also suggested policies for 64 
farmers who are unable to participate in the commodity market to trade their goods. Srinivasan (2008) studied the impact of the price and risk on crops before and after the implementation of the ban taking four main commodities namely - potato, chickpea, soyoil and rubber all of which was banned during the same time. Her report argued that banning destructs the healthy running of a market and is completely illogical as it did not at all help in curbing rise in food price. There has been a vast amount of literature written against this background, however compared to the world commodity market minimal work has been performed on the agricultural commodity market. This study looks at the futures market in agricultural commodities with the effect of the ban on the futures trade as a subtopic.

The research objectives are formulated below:

- To study the effect of futures trading on agricultural commodity market in India

- To examine the effect of the ban on futures trading and whether it was logical

- To propose some policy measures for the efficient running of the market

\section{Data Analysis}

To carry forward the analysis of futures trading in agricultural commodities secondary data ${ }^{6}$ on prices and other important variables have been compiled. To begin the analysis, seven commodities were taken. The seven commodities are: Wheat, Rubber, Potato, Sugar, Chickpea, Rice, Guar Seeds. The reason behind selecting these seven commodities is because these commodities were banned more or less during the same period. Keeping the timeframe in mind, the commodities were carefully selected. Rubber, potato and sugar were banned from May 2008 to November 2008. Sugar was banned for a longer period from May 2009 to October 2010. For wheat, the ban was for around two years from March 2007 to May 2009 and the most recent ban that was implemented and lifted was Guar Seeds which was from March 2012 to May 2013. Rice, however, is the only commodity upon

${ }^{6}$ NCDEX (National Commodity Derivatives Exchange); MCX (Multi Commodity Exchange); AGMARK. 
which the ban has not been lifted. The wholesale monthly prices for the past seven years (2006-12) were tabulated and the mean and standard deviation of the prices for each commodity was calculated. The prices ${ }^{7}$ for each commodity were the prices of that state where the commodity was traded the most. Below is a table that depicts the commodity and the state in which it is traded the most.

Table 1: List of selected commodities and the states in which they are traded the most

\begin{tabular}{|l|l|}
\hline \multicolumn{1}{|c|}{ Commodity } & \multicolumn{1}{c|}{ State } \\
\hline Wheat & Rajasthan \\
\hline Rice & West Bengal \\
\hline Sugar & Uttar Pradesh \\
\hline Potato & Uttar Pradesh \\
\hline Rubber & Kerala \\
\hline Chickpea & Maharashtra \\
\hline Guar Seeds & Rajasthan \\
\hline
\end{tabular}

Descriptive statistics were performed for each of the commodities (mean and standard deviation) and a comparative analysis of the same was made both before and after the ban. This was done in order to see whether or not the price was affected by the ban and if so what the intensity was.

For rice, the table is left blank as the ban on futures trading for rice which was implemented in the year 2007 has still not been removed. Thus the intended study could not be performed for the same. From Table 2 it can be safely assumed that the ban was not at all effective in curbing the rise in price over the years. In fact commodities like rubber and sugar, the prices rose to a very high level.

A price trend line for each commodity was drawn and the period in which the ban was implemented is shown diagrammatically. This makes it easier to analyze the impact of the ban on the commodities

\footnotetext{
7 Agricultural Marketing Information Network - Price Trends 66
} 
Futures Trading in Agricultural Commodities Artha J Soc Sci, 12, 4 (2013)

Table 2: Descriptive statistics of wholesale prices for each of the selected commodities

\begin{tabular}{|c|c|c|c|c|c|c|}
\hline 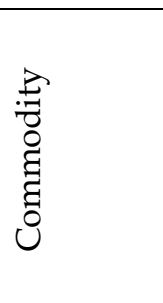 & 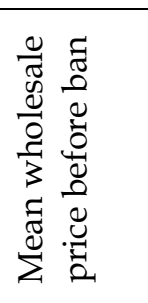 & 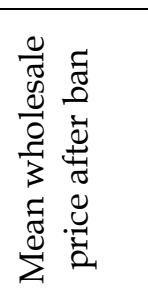 & 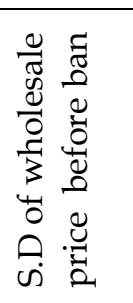 & 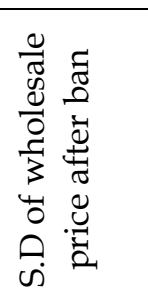 & 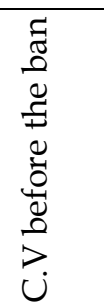 & 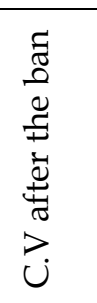 \\
\hline Wheat & 918.7229 & 1245.492 & 91.67 & 137.11 & 9.97 & 11.00 \\
\hline Rice & - & - & - & - & - & - \\
\hline Sugar & 1765.839 & 3109.52 & 269.29 & 323.4 & 15.24 & 10.40 \\
\hline Rubber & 8971.243 & 15412.23 & 871.49 & 4819.029 & 9.71 & 31.26 \\
\hline Chickpea & 2253.502 & 2889.741 & 239.54 & 837.816 & 10.62 & 28.99 \\
\hline Potato & 484.24 & 622.53 & 158.15 & 300.14 & 32.65 & 48.21 \\
\hline $\begin{array}{l}\text { Guar } \\
\text { Seeds }\end{array}$ & 1915.48 & - & 1037.86 & - & - & - \\
\hline
\end{tabular}

\section{Effect of the Ban}

The period of ban for wheat was March 2007 to May 2009 which is shown by the vertical lines on the graph. In March 2007, the price hovered around Rs 900/quintal while the price that prevailed on and after May 2009 was close to Rs. 1200/quintal which accounts for a $22 \%$ increase approximately in the period of 14 months. This clearly goes against the logical solution of the government that was responsible for implementing the ban for the sole purpose to curb the increasing prices.

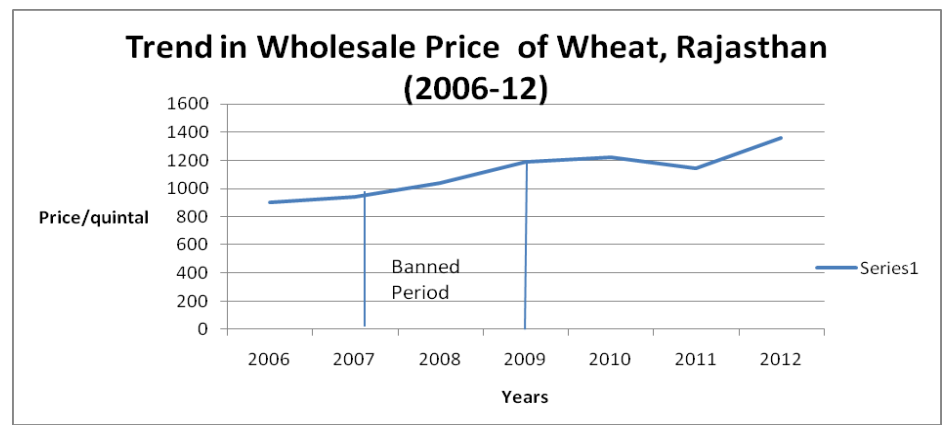

Fig 1: Graph depicting the trend in wholesale prices of wheat from 2006-12 


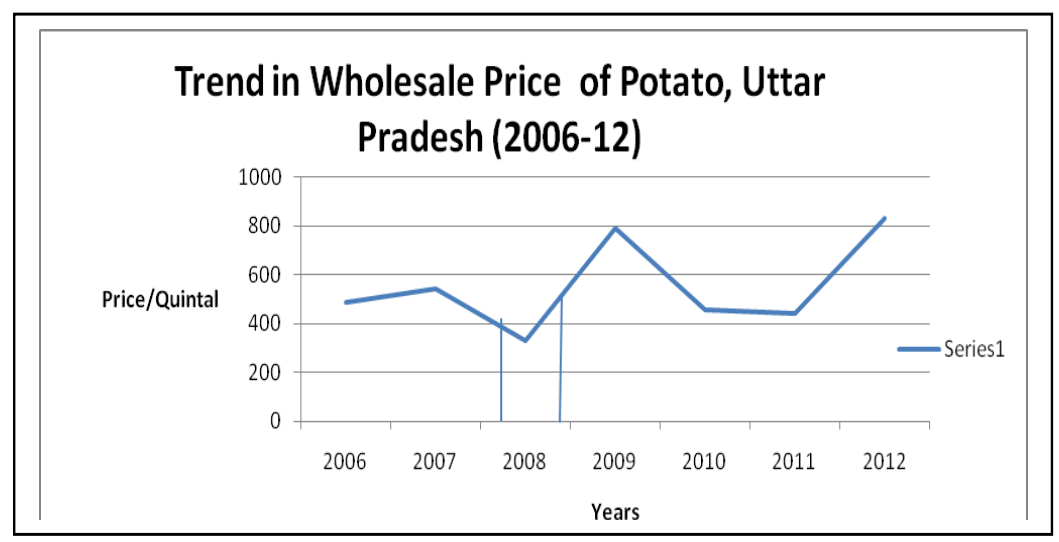

Fig 2: Graph depicting the wholesale price in Potato for the period 2006-12

For potato, the ban period lasted for six months from May 2008 to November 2008. The prices for potato were very volatile as it experienced a dip in the initial few months of the period of ban and then increased spontaneously. Here again, the ban had no real effect on the prices and hence the ban seemed redundant. The decrease in price which is shown after the ban was a general past trend which would have continued had the ban not been placed too.

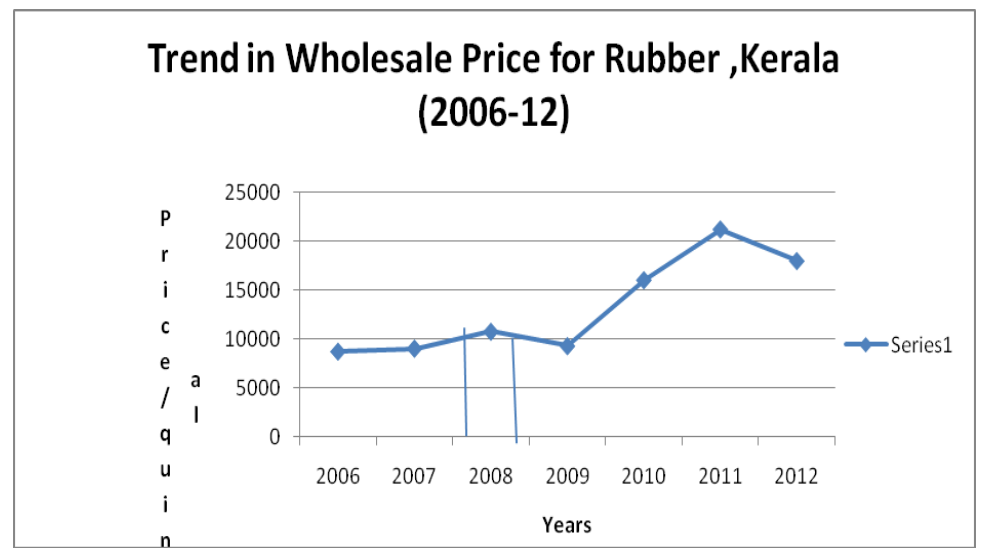

Fig 3: Graph depicting the trend in the wholesale price of rubber from 2006-12

Rubber was also banned during the same time period and span as that of Potato, namely for six months. The vertical line shows the period of the ban (the time the ban was implemented). Price of rubber also witnessed an up-down trend with respect to its prices 
and the ban did not help at all in curbing inflation but in fact led to de-stabilization of prices. The average price fell in the year 2009 (after the ban was lifted) from Rs 10685 per quintal to Rs. 9215 per quintal, however it was only a short term gain. In the long run however the price went up all the way to Rs 21000 in the year 2011. This is just similar to the case of sugar where in the immediate year after the ban was lifted the price showed a decreasing trend however in the long run the price increased at an increasing level thus violating its intended purpose. Sugar as a commodity shall be studied further in this paper.

Another commodity which was banned in and around the same time was chickpea. Chickpea is also commonly known as Chana or Bengal Gram. Chana, as a commodity, in the futures market was banned by the Government of India for a period of six months.

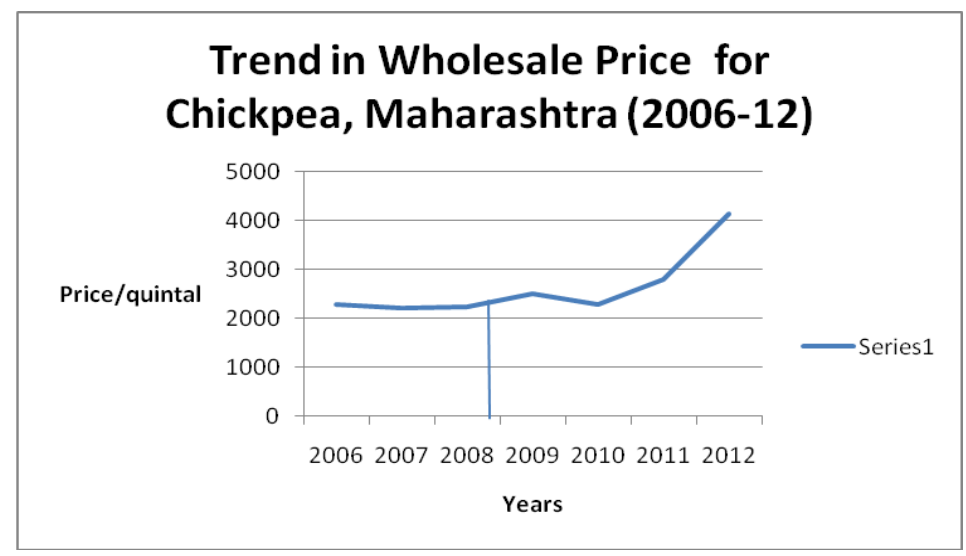

Fig 4: Graph depicting the trend in wholesale price of chickpea from 2006-12

The vertical line depicts the period of ban. Again, since the period of the ban was too short (less than a year) a single line is drawn. For Chickpea, the ban was not fully effective, but was the least ineffective as there was only a mere $2 \%$ increase in the price post the lifting of the ban. Thus when compared to the rest of the commodities chickpea was least affected by the ban and thus the degree of volatility was comparatively lower.

\section{Sugar}

The major trading state for sugar is Uttar Pradesh. Keeping this in mind, the wholesale prices for the year 2006 to 2012 was collected and a trend price line was formulated. Sugar was also one of those 
commodities that was banned by the Government of India in the year 2009 (May) and lasted till 2010 (October) which was approximately 17 months. Fig 5: Graph depicting the trend in the wholesale price of sugar from 2006-12

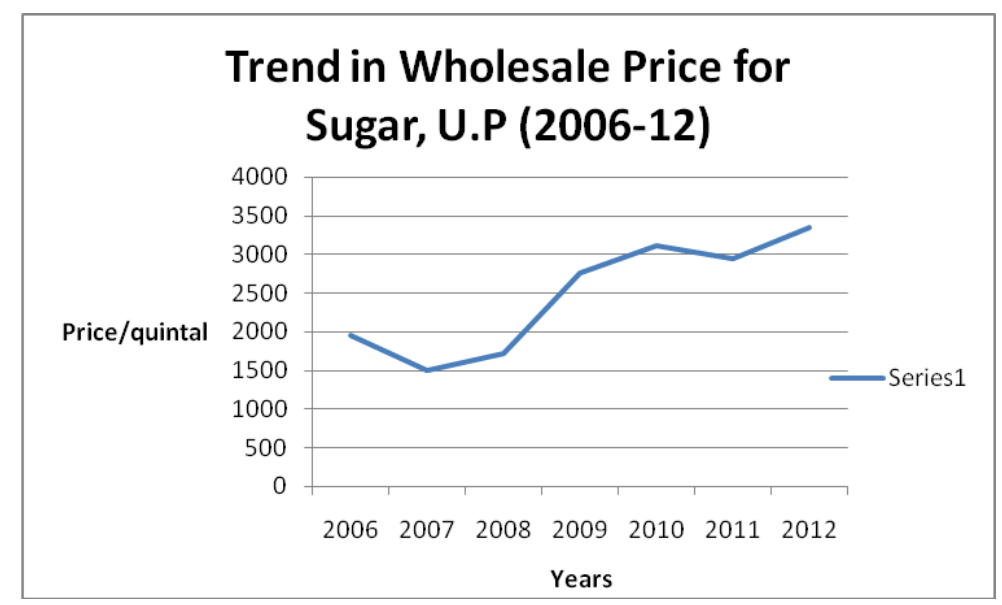

Figure 5 has been plotted using the wholesale prices for sugar from the year $2006-2012$.

We notice that the price prevailing as of May 2009 was Rs. 2560 per quintal, just when the ban was implemented. Once the ban was lifted on October 2010, the mean price is Rs 2938 per quintal in 2011 from the previous mean price of Rs 3105 per quintal in 2010. This gives us an idea that the ban may have had an impact on the immediate short run but gradually had an adverse overall impact.

For guar, the ban was recently removed (May 2013) after around 14 months since the ban was implemented in March 2012. Thus much post ban analysis could not be done for the same. However it was seen that the mean price for guar has also been rising throughout the year. The mean price for guar seeds in the year 2006 read Rs. 916 per quintal whereas at the end of 2012 the mean price rested at Rs 2625 per quintal, which is approximately $187 \%$ increase in six years or around $26 \%$ each year. 
Futures Trading in Agricultural Commodities Artha J Soc Sci, 12, 4 (2013)

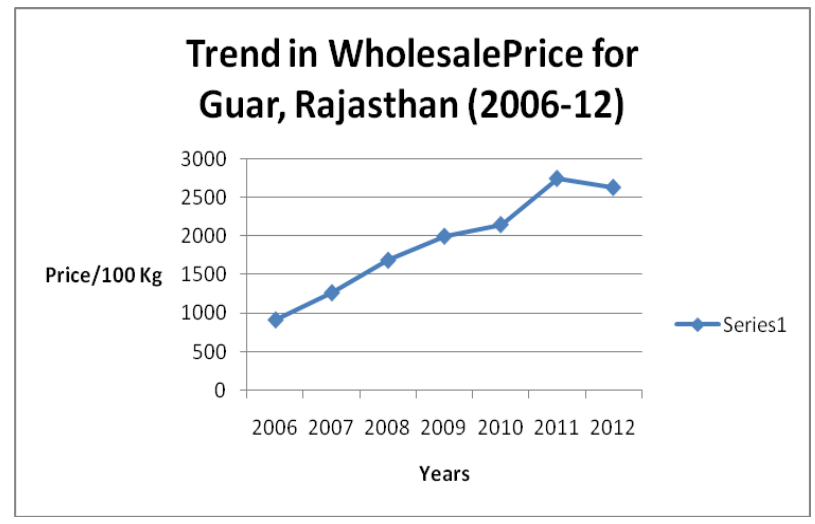

Fig 6: Graph depicting the trend in wholesale prices of guar from 2006-12

The uprising prices can be analyzed from Figure 6 itself. Again much cannot be said about the post ban analysis as the ban has just been lifted. For rice, the ban is still on. The ban was implemented five years back in the year 2007 and till now the Government of India has not allowed rice to be traded in the futures market. Rice, as we all know, is an essential agricultural commodity. The current price of rice is around Rs. 2100 per quintal. However till now the price of rice has not decreased despite the ban not been removed. As stated earlier, the demand for rice is inelastic. Rice being an essential commodity has a very high demand and thereby any such imposition by the government is not going to in any way help in curbing the rising price.

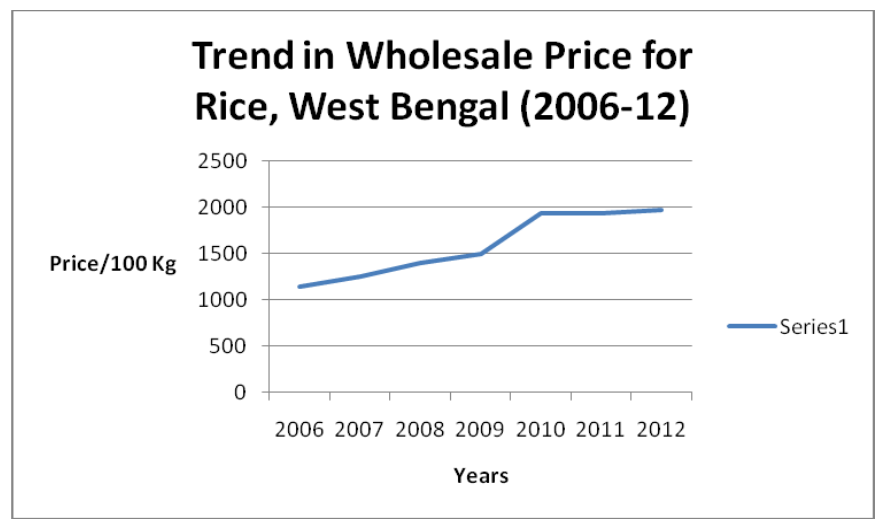

Fig 7: Graph depicting the trend in wholesale price of rice from 2006-12 
Result: We can clearly see that for all commodities, the mean price had risen even after the ban was imposed. This clearly tells us that the ban was redundant and the purpose was not at all fulfilled. Even the standard deviation for all commodities is indeed high which means that the deviation from the mean price is the maximum. The coefficient of variation was then calculated for the six commodities (except rice). The CV is a statistical measure the ratio between the standard deviation and the mean. Furthermore, the $\mathrm{CV}$ tells us the degree of variation between two sets of observations having considerable different means. Noticing carefully, we see that the $\mathrm{CV}$ is maximum for potato both before and after the ban for the years 2006-12. It is also seen that the coefficient of variation has increased for all commodities after the ban (apart from sugar). This is because of the sole reason that the standard deviation has increased by a higher rate than the mean in the two periods. The correlation coefficient between the two sets of prices is also the maximum between the two sets of prices (before and after ban).

\section{Correlation Analysis}

Given the perpetual increase in the price of rice throughout, an analysis has been done to see whether if wheat and rice are taken to be substitutes (as goods) what would the resultant effect turn out to be 0.7809 . Given the high correlation coefficient between both the goods, we can say that the prices of both goods move in a unidirectional manner.

Next a simple correlation analysis was done between two sets of wholesale prices both before and after the ban. Again the reason behind such an exercise is to check whether the ban was effective in changing the direction of the prices. This was done for each of the commodities.

Wheat: The period of the ban for wheat was from March 2007 to May 2009. The wholesale prices till March 2007 were collected and correlated with the prices after May 2009 such that the number of variables is the same for both periods. The correlation coefficient turned out to be -0.202 . A negative correlation coefficient reminds us that the prices took an opposite direction after the ban. However 72 
this goes against our previous study which suggests that the ban was ineffective in curbing the price rise. Therein lays the error. This error is however because of the fact that there was an immediate drop in prices in the year 2011; however, in the later years the price rose by a huge margin. The percentage increase in price from 2011 to 2012 itself recorded a $20 \%$ increase. Since the number of variables necessarily have to be the same for calculating the correlation coefficient, the prices for 2012 had to be ignored leading to a negatively correlated value.

Potato: For Potato, the correlation coefficient between the two sets of prices was the highest among all other commodities. The correlation coefficient is 0.839 . This tells us that the price movement is correlated to a very high level. The price movement for potato is however not in a single direction. If carefully noted, we see that year 2006-07 recorded an upswing in prices and an immediate downfall for the immediate next year. The same pattern was recorded for the prices after the ban. Year 2008-09 recorded an increase in prices (though by a greater percentage than 2006-07) but again followed the trend by an immediate fall in prices for the next year. This is sufficient enough to explain the highly correlated value between the two sets of prices.

Rubber: Rubber, as compared to other commodities witnessed a very high wholesale price of approximately Rs 13000 per quintal. The correlation coefficient between the two sets of prices is 0.48 .This is not a very high value $(<0.5)$ and hence not significant.

Sugar: The ban for sugar lasted for approximately 17 months. May 2009 the ban was implemented by the Government of India and was lifted in October 2010. The correlation coefficient between the two sets of prices (before and after ban) recorded a negative value of

-0.445 . This can be explained by the fact that there was an increase in the price from 2008 to 2009 by $14.81 \%$ but decreased from 2009 to 2010 by around $6 \%$. However this cannot be said to go against the fact that the ban was not all that useful as again the price witnessed an increase in the next year by around $14 \%$.

Chickpea: The ban period for Chickpea was the same as Potato and Rubber as they were banned together for the same duration (May 
2008- Nov 2008). Chickpea showed a positive correlation between its two sets of price, however, did not have a very high value yet again to be significant.

Table 3: List of selected commodities with the correlation coefficient between the two sets of wholesale prices (before and after ban)

\begin{tabular}{|l|l|}
\hline Commodity & Correlation Coefficient \\
\hline Wheat & -0.202 \\
\hline Potato & 0.839 \\
\hline Rubber & 0.480 \\
\hline Sugar & -0.445 \\
\hline Chickpea & 0.440 \\
\hline
\end{tabular}

Summary: The correlation coefficient is seen to be the maximum for potato (also has the highest C.V) whereas the one with the least correlation coefficient is sugar because of the fall in prices immediately after the ban. Although prices fell down for rubber too, the value is still positive as a larger number of observations were taken thus taking into consideration the increasing prices in the following years. For the rest of the products the value is moderate closing at somewhere near to 0.5 .

\section{Effect of the Ban on Quantity Traded}

In the previous sections, we have studied the impact of the ban on the prices for the commodities. In the following section a comparative analysis of the commodities shall be done, this time for the amount traded. For the period of study (2006-12) the quantity traded for each of the commodities in the study was collected $^{8}$. The purpose was to check whether the ban on futures trading in agricultural commodities by the Government of India had an adverse or favorable impact. However, data for all commodities and for all years were not available and hence analysis was performed only for the given data.

\footnotetext{
${ }^{8}$ http://www.mcxindia.com/SitePages/HistoricalDataForVolume.aspx 74
} 
Futures Trading in Agricultural Commodities Artha J Soc Sci, 12, 4 (2013)

For wheat, potato, rubber and guar considerable amount of data was available for most of the years.

Table 4: Amount of futures quantity traded in wheat from 2006-12

\begin{tabular}{|l|l|l|l|l|l|l|l|}
\hline Years & 2006 & 2007 & 2008 & 2009 & 2010 & 2011 & 2012 \\
\hline $\begin{array}{l}\text { Qty } \\
\text { ('000 Kg) }\end{array}$ & 925480 & 3370 & 0 & 868620 & 46760 & 1920 & 20 \\
\hline
\end{tabular}

The period of ban for wheat was from March 2007 to May 2009. A point to note here is that there was no wheat traded in the futures market in the year 2088 (middle of the ban period). It is also very clearly visible that the amount of wheat traded decreased drastically after the ban was lifted. Thus there exists an adverse impact of the ban on the quantity traded in wheat.

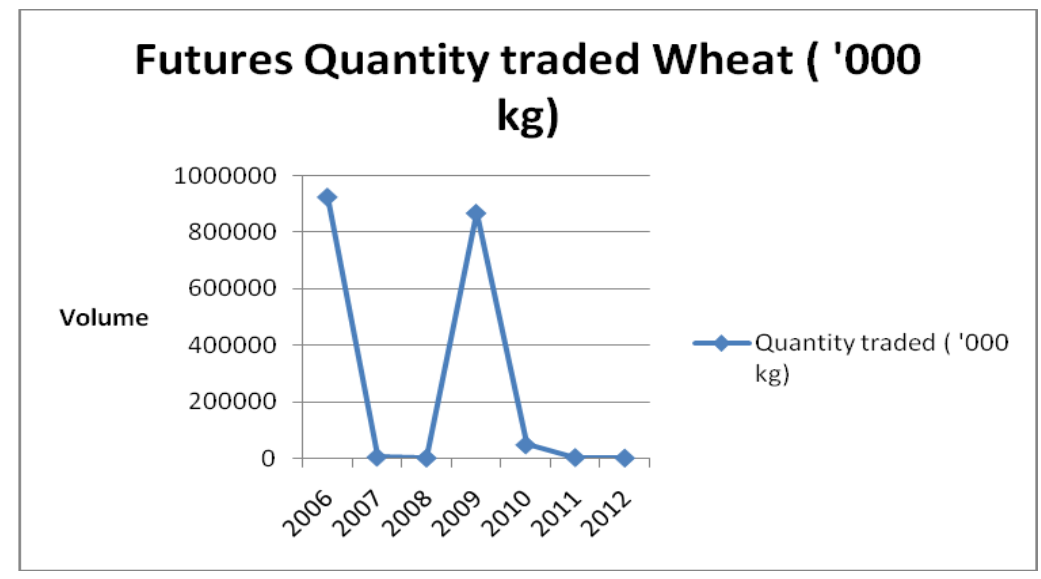

Fig 8: Graph depicting the futures quantity traded in wheat from 2006-12

Table 5: Amount of Futures quantity traded in potato from 2006-12

\begin{tabular}{|l|c|c|c|c|c|c|c|}
\hline Years & 2006 & 2007 & 2008 & 2009 & 2010 & 2011 & 2012 \\
\hline $\begin{array}{l}\text { Qty } \\
(‘ 000 \mathrm{~kg})\end{array}$ & 11937240 & 12681690 & 1170270 & 2699070 & 14755560 & 14014500 & 8221410 \\
\hline
\end{tabular}

For potato, the story is a little different. The quantity traded increased by a huge amount immediately after the ban was lifted. 
Unlike other commodities, the ban did not have any adverse effect on the quantity traded at all. In fact potato witnessed a huge increase in its price too despite the ban. One possible reason for this could be because of the fact that potato is one of the essential commodities for rural as well as urban India and therefore no governmental intervention whatsoever can violate the law of economics.

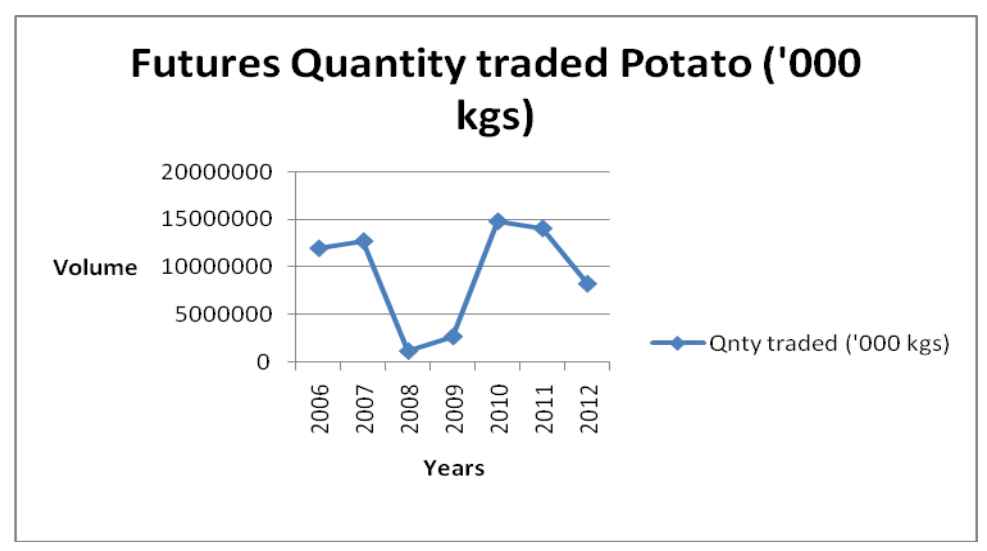

Fig 9: Graph depicting the futures quantity traded in potato from 2006-12

From Figure 8 above it is clear the after the ban was lifted in the year 2008 the quantity traded increased which is but normal. This implies that the ban on futures trading in potato did not have an adverse impact on the quantity being traded.

RUBBER: Another such commodity where the ban had an adverse impact on the quantity traded was rubber. Rubber had a ban period of six months.

Table 6: Amount of Futures quantity traded in rubber from 2006-12

\begin{tabular}{|l|l|l|l|l|l|}
\hline YEARS & 2006 & 2007 & 2008 & 2009 & 2010 \\
\hline Qty Traded & 53551 & 56036 & 1368 & 201 & 6 \\
\hline
\end{tabular}




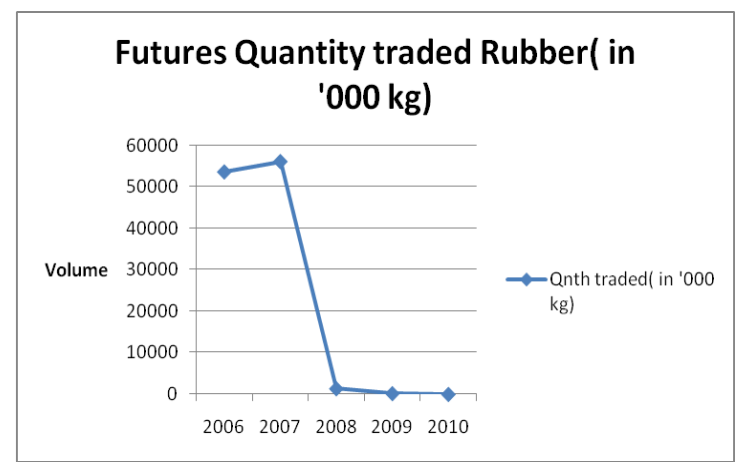

Fig 10: Graph depicting the futures quantity traded in rubber from 2006-12

From Table No.6 and Figure No. 9 above it can be seen that the amount of quantity traded almost went to single digits by the end of 2012. Thus it can easily be inferred that the ban did have a very bad impact on the quantity traded. In fact the quantity traded for rubber fell to an all time low and also the lowest among all other commodities.

The same trend follows for Guar Seeds. The fourteen month old guar seed ban was recently removed in May 2013 (the ban was implemented in March 2012). The quantity traded in guar also started fading out in the years. This clearly tells us that the futures trading had an adverse impact on the quantity traded for almost all the commodities, apart from potato. Another implication from this section of study tells us that the amount of quantity traded has no direct relationship with the wholesale prices for each commodity prevailing in the market. As the prices move in an upward direction immediately as the ban was lifted, the quantity traded started to decrease. The analysis of price was studied in the previous section. Thus the wholesale price and the futures quantity traded have a negative relation between them which will be analyzed further in the next section.

Table 7: Table demonstrating the amount of futures quantity traded from 2006-12

\begin{tabular}{|l|l|l|l|l|l|l|l|}
\hline $\begin{array}{c}\text { Years } \\
\text { Quantity }\end{array}$ & 2006 & 2007 & 2008 & 2009 & 2010 & 2011 & 2012 \\
\hline Wheat & 925480 & 3370 & 0 & 866820 & 46760 & 1920 & 20 \\
\hline Potato & 11937240 & 12681690 & 1170270 & 2699070 & 14755560 & 14014500 & 8221410 \\
\hline Rubber & 53551 & 56036 & 1368 & 201 & 6 & - & - \\
\hline
\end{tabular}

\subsection{Regression Analysis}

A simple regression analysis was performed using the wholesale price and quantity for four of the seven commodities. Due to 
unavailability of data all commodities could not be taken into account. To overcome this difficulty the data has been pooled taking the quantity on one side and price on the other side. The period of duration is 2006-12 which has remained the same throughout the study.

Regression: The independent variable here quantity, also known as the explanatory variable while the dependent variable here is price, also known as the explained variable. Thus on the y-axis, the wholesale price variable has been taken while on the $x$-axis, futures quantity traded has been taken. The regression model that has been worked out in this study is a log-log model.

After running the regression of price over quantity, the regression equation that we get is as follows: $Y=9.114-0.146 X$. The interpretation of the aforesaid regression equation is different from a normal regression equation. For a $1 \%$ increase in futures quantity traded, price decreased by $0.146 \%$. This clearly tells us that there exists a negative relationship between the wholesale price and the quantity traded for each commodity. Again from the table we see that the R Squared value is 0.35 which is nothing but the coefficient of determination. It tells us how well the regression line fits the data. In this case the fit is not very good, as it is less than 0.5.

\subsection{Inflation}

Inflation is defined as the significant increase in price rise. In this following study we have focused on agricultural commodities and the impact of futures trading on them. Out of our seven commodities in the given sample, six of them are food commodities and only rubber is the non food commodity. Thus given the skewed distribution towards food commodities it is but just to accommodate and carry forward our analysis with respect to food inflation under the WPI Index. The Wholesale Price Index has been recorded keeping 2004-05 as the base year. The values for the following years 
Table 8: Wholesale Price Index and the corresponding percentage change from 2006-12

\begin{tabular}{|c|c|c|}
\hline Years & WPI & Percentage Change \\
\hline $2006-07$ & 111.4 & - \\
\hline $2007-08$ & 116.6 & 4.66 \\
\hline $2008-09$ & 126 & 8.06 \\
\hline $2009-10$ & 130.8 & 3.80 \\
\hline $2010-11$ & 143.3 & 9.55 \\
\hline $2011-12$ & 156.1 & 8.93 \\
\hline
\end{tabular}

Source: Statistics of Hand Book of India, Reserve Bank of India

From Table No. 7 it is seen that the percentage change in the Wholesale Price Index is increasing by a phenomenal rate. The year 2009-10 however witnessed some moderate change with the rate stabilizing at around $4 \%$. However the use of the WPI has been questioned by many experts. For instance a delay in data collection can lead to significant differences in final inflation figures. Though the Consumer Price Index is considered to be a more advanced instrument for reporting inflation, it is not viable to be used in India because there is too much of a lag in reporting the CPI numbers. Another point of debate exists with the fact that the Consumer Price Index is calculated on a monthly basis whereas the Wholesale Price Index is calculated on a weekly basis which is considered to be more appropriate for India.Thus given some of the problems with the normal rate of inflation, we now focus only on food inflation for our period of study (2006-12). India's food inflation remains above the comfort level of the government and consumers posing a big challenge for policymakers. Rating agency Moody's in a report stated that the food prices in India were rising faster than the global rate. On one hand when the World Bank food price Index started to rise by $3 \%$ on a year on year prices for the past 12 months, India's food prices increased by almost $10 \% 9$. This itself is proof enough to demonstrate the high food prices in India as compared to the rest of the globe.

9 'India food prices rising faster than global increase': Zia Haq, Hindustan Times 
Given the statistics, we now need to analyze the reason for such an alarming result and need to address the issue with progressive policy measures. Reasons why food prices have remained sticky have been analyzed by economists. For example, the drought in states like Maharashtra will cut food output drastically. Also on the supply side, minimum support prices and high farming costs are major factors that lead to food inflation. Thus food inflation is one of the major components leading to overall inflation in the economy. Wholesale Price Index for food articles were collected 10 and comparative analysis over the years were done. The Base year considered was 2004-05.

Table 9: Wholesale Price Index for food articles from 2006-12

\begin{tabular}{|l|l|}
\hline Years & WPI - Food Articles \\
\hline $2006-07$ & 115.5 \\
\hline $2007-08$ & 123.6 \\
\hline $2008-09$ & 134.8 \\
\hline $2009-10$ & 155.4 \\
\hline $2010-11$ & 179.6 \\
\hline $2011-12$ & 192.7 \\
\hline
\end{tabular}

There was an overall 69\% increase in the index from 2006 to 2012. This is in fact a very high growth rate when compared to other countries. The following column diagram below diagrammatically represents the above stated statistically proven fact

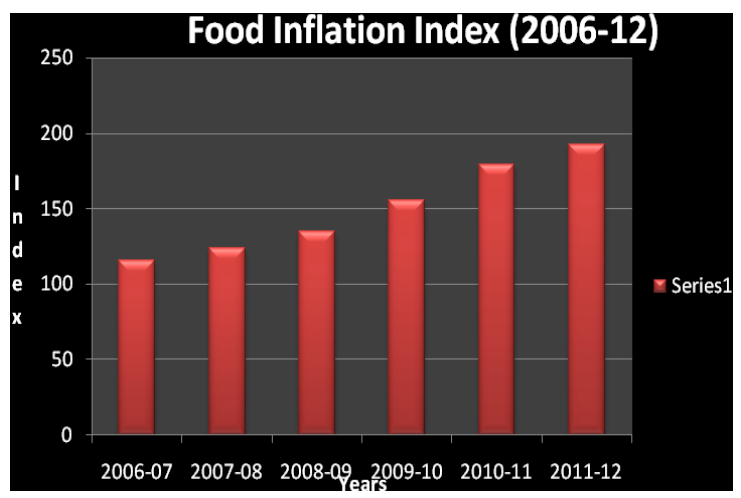

Fig 11: Column Diagram depicting Food Inflation Index from 2006-12

10 Handbook of Statistics for India: Reserve Bank of India 
The question that needs to be answered and addressed particularly over here is that does futures trading lead to inflation or is it just a myth. The Reserve Bank of India stated that there is no conclusive evidence to show that futures trading in agricultural commodities lead to inflation. This result by the Reserve Bank of India is in accordance with the study by the Abhijit Sen Committee which was formulated in the year 2007 specifically to study the impact of futures trading on pricing of agricultural commodities. Using the well known econometric tool - Granger Causality test, a study by the RBI found out those prices in agricultural commodities seemed to be influenced by other drivers of price change like demand supply gap of specific commodities, degree of dependence on imports and international movement in these commodities. While futures prices had a causal relationship on spot prices for urad and sugar, it was the reverse in case of chickpea and wheat ${ }^{11}$. Thus the empirical analysis does not give us any sort of evidence in support of relationship between futures prices and spot prices. According to Madan Sabnavis, chief economist, Care Rating and former chief economist of NCDEX - 'The RBI diagnosis reinforces what has been held all along by the futures market that futures prices do not cause spot price inflation and hence cannot be held responsible for food inflation in essential commodities'.

The main aim of futures trading is to offset the market risk and to provide better prices to producers, marketer and consumers. 'That futures trading in commodity market causes inflation is a spurious correlation $^{12}$ ' stated by Prabhakar Patil, Director, Forwards Market Commission. It is a historical trend that futures markets are the first ones to be blamed when it comes to inflation. The speculative nature of the futures market is the Achilles heel of the market. A market mechanism that is more efficient and viable for risk management is the use of the futures market. Having a look from a macroeconomic point of view, given the vast amount of stakeholders, a considerable amount of risk is considered appropriate. The only problem that exists in such markets is that

11 'No proof of commodity futures trades impacting inflation' - Study by RBI.

12 'India's inflation fans futures anger' - Article by Raja M published by Asia Times 
they do not have a macro economic perspective thus being a disadvantage to mostly the small rural farmers who have meager resources to their disposal. The macro development approach however demands that the market also performs activities like financial intermediation in order that the savings and investment rates rise at a fast rate and higher levels of GDP and employment is achieved ${ }^{13}$.

Causes of Inflation: Amartya Sen suggested that inflation; especially food inflation is caused because of the practice of hoarding by famers and middlemen do causing the demand supply gap. The demand supply asymmetry can only be decreased by the increase in the overall production of high value foods like soya bean, potato and banana ${ }^{14}$. Indians are now spending a huge sum of money on foods with consumption pattern being shifted a lot. A report by 'The India Express' stated that the key cause was however low technological advancements by the farmers. The key change was to make more agro crop run through the value added chain. It was also studied that the cut in subsidies and price hikes of inputs like diesel and fertilizer also contributed to food inflation. The deregulation of petrol prices led to a steep hike in food price. Thus futures trading are not the one and only cause of food inflation. Futures trading may have a small role to play in increasing prices but this is solely because of the volatility in the market. If price is made stable and price stability is achieved then the futures trading will have a minimal effect on the overall prices. When we use the word market here we take into consideration foreign markets too as export and import do affect the domestic prices to a large extent. On the other hand there are some states in India that are promoting futures trading 15 . For example, the government of Uttar Pradesh went a step ahead by insulating the risk farmers could have incurred. They supported futures trading in the agricultural commodity market which is helpful in hedging.

13 Prices Stability and Futures: Need for macro developmental frameworkArticle by Kalyan Raipuria; Economic and Political Weekly.

14 Joint Report by Confederation of Indian Industries and Mc Kinsey and Company, FAIDA

15 'U.P to promote futures trading in agricultural commodities': Article by Business Standard 
This is a part of the comprehensive plan towards a farmer friendly marketing set-up in the state. During the $12^{\text {th }}$ year plan, Uttar Pradesh is targeting a growth rate of $5.1 \%$. This is a bit short of the industrial growth rate being pegged at $7.1 \%$. This is yet another proof of giving agriculture the second hand.

Statistically speaking India's population is growing at a rate of $1.4 \%$ per year. Also, the Indian economy is growing at an average of $8 \%$ per year while agricultural growth rate is growing at a meager rate of $3.5 \%$. The increasing population is demanding food while the slowdown in agricultural production (as compared to the rest of the economy) incumbent to slowdown in technology leads the demand-supply gap to widen. The solution to food inflation is simple. India needs to focus on production and increase the supply. Banning of futures trading and other activities pushed towards curbing inflation is redundant.

First and foremost reason for the rising prices in food commodities is the shift in dietary pattern. Majority of the Indian population has in the recent past shifted their dietary patterns to mainly proteinaceous items like meat, milk and other such food items. Statistically, food with high amount of protein content in them exceeded headline inflation leading to an overwhelming increase in prices. However the demand for food items filled with proteins has not been captured by the supply leaving a scope for a gap in between hence in turn leading to inflation.

Another issue that needs to be addressed is the Minimum Support Prices for various agricultural commodities. The minimum support price policy for agricultural commodities is the minimum selling price a seller can possibly charge. Now in the recent past, there has been an increase in the minimum selling price thus leading to an overall increase in prices and thereby escalating food inflation level. The Commission for Agricultural Cost and Prices follow a cost up pricing policy for determining the MSP. Given the cost plus pricing formula, it is but just for the prices to rise. Another factor that needs to be given equal importance is the rising global prices of food commodities. It was seen that import barriers and increasing prices of food commodities abroad do impact the prices in the domestic sector. In fact the OECD-FAO Agricultural Outlook 2011-20 indicates that the prices may even be higher in real terms 
during the period 2015. Yet for primary food articles like wheat and rice, the domestic price is even higher than global prices. Thus given the increase in consumption for such commodities, import practice will not be beneficial.

\subsection{Policy Measures to Control Food Inflation}

Having addressed the causes of inflation in the previous section in a brief manner, the paper is now going to analyze the different policy measures that the government of India along with the Central Bank can accommodate to mitigate the effect. The first and immediate measure that needs to be worked upon is the agricultural productivity. We have spoken enough about the demand supply gap in the previous sections. To bridge this gap it is essential that agricultural productivity is looked into.

Agricultural Productivity: The Green Revolution is one such measure take up to increase the yield amount by a very large extent. However, if compared to the rest of the world we are still lagging behind. To quote a few numbers, India had witnessed the highest amount of oilseed production in the period 2010-11 with a production level of 2.1 tonnes per hectare which is still low as compared to 2.7 tonnes in U.S. Also there has not been any kind of significant breakthrough in the technological level right from the Green Revolution. Another natural reason for such a drop in production is assigned to unfavorable climatic changes.

MSP: A large number of subsidies in the agricultural market are also a major cause for such a downfall. Inputs (fertilizers) and output (public distribution system) are both subsidized. This puts a huge pressure on the fiscal account. Over and above this, minimum support prices should also be regulated. In other words, if the amount that is assigned for subsidies is given for capital formation then perhaps productivity would increase thus lowering the price for the consumers and increasing the yield for the farmers. The table shown below gives us a glimpse of the same 
Table 10: List of macroeconomic indicators for the Indian economy from 2008-12

\begin{tabular}{|l|l|l|l|l|l|}
\hline & $2008-09$ & $2009-10$ & $2010-11$ & $2011-12$ & $2012-12$ \\
\hline GFD/GDP & 6.0 & 6.5 & 4.8 & 5.7 & 5.1 \\
\hline CAD/GDP & -2.3 & -2.8 & -2.8 & -4.2 & -4.6 \\
\hline GDP & 6.7 & 8.6 & 9.3 & 6.2 & - \\
\hline Agri GDP & 0.1 & 0.8 & 7.9 & 3.6 & - \\
\hline Nominal & 10.7 & 15.8 & 18.3 & 19.8 & 18.4 \\
\hline Real & 0.6 & 2.1 & 8.3 & 11.5 & 9.2 \\
\hline
\end{tabular}

Note: GFD: Gross fiscal Deficit. GDP: Gross Domestic Product; CAD: Current Account Deficit Source: Reserve Bank of India

From Table No. 9, we can carefully imply that both fiscal and current account deficits have increased throughout the years whereas agricultural growth has stagnated. To overcome this stagnation, the Government should introduce supply chain management. Talking about supply chain management, two important issues that needs to be addressed is

a) Foreign Direct Investment

b) Public Distribution System

Supply Chain Management: Management of food stock has always been a debatable issue. Given the leakages that have been observed under the PDS system, a lot of alternatives have come up; however none of them are without any problems. Given that the stem of the problem is food filled with proteins like milk, egg, butter and meat which is perishable, it is suggested that the supply chain management is strengthened. This can be carried out by allowing FDI into multi brand retail.

\subsection{Conclusion}

Inflation has a regressive effect for both the producers and the consumers. It tends to destabilize the economy leading to a slowdown in the growth rate. India's headline inflation has reached double digits and is increasing at an unimaginable rate. It is time the government takes a measure. The Government in the recent past has taken quite a few steps, one of which has been the major thrust of the study, however banning the futures market is not a logical solution. It might lead to a favorable outcome in the short 
run as seen in some commodities, however, to put a stop and to curtail the level of food inflation to a healthy level, the Government needs to work alongside the Reserve Bank to tighten some of the measures stated in the previous section.

This paper has dealt with a very common topic which has been one of the major worries for the Indian economy. A simple analysis taking the spot prices and the ban period showed that banning future trading in the agricultural commodity market does not actually help the cause (curtailing food inflation). An efficient futures market indeed curbs price volatility and hedging future market conditions under adverse situations. Finance Minister of India P.Chidambaram had helped the futures traders by sparing them of a commodity tax which would push up the inflation rate ${ }^{16 .}$ Instead a tax of $0.01 \%$ was imposed on non agricultural futures.

Thus to sum it up all, this paper has done a micro study on the agricultural commodity market by taking seven commodities upon which the ban was placed. With the help of descriptive statistics and a simple regression analysis, results have been obtained which is at par with other studies. The main focus of this paper was however not food inflation but how effective was the ban placed on certain commodities to curb food inflation. In this aspect, the paper has also suggested some policy measures which needs to be carefully studied and implemented if feasible by the Government in order to help the common man from the gravity pull towards helplessness and poverty. Dr Manmohan Singh once said - "Food inflation may be the result of growing prosperity" but does this growth include inclusive and overall growth. This leaves scope for further debate and study.

\section{References}

Bakaert, G., \& Harvey C.R (1997). Emerging equity market volatility. Journal of Financial Economics.

Bekiros, S, D., and Diks, C. G. H. (2008). The Relationship between Crude Oil Spot and Futures Prices: Cointegration, Linear and Non linear Causality.

16 'To control food inflation, agricultural commodities spared futures tax' Article in Hindustan Times. 
Carter, C. A (1989). Arbitrage opportunities between thin and liquid future markets. The Journal of Future Markets.

Garbade, K. D., and Silber, W.L. (1983), 'Dominant satellite relationship between live cattle cash and futures market', The Journal of Futures Market.

India food price rise faster than global increase. Study by Zia Haq. Published in Hindustan Times.

India's inflation fans futures anger. Study by Raja M. Published in Asia Times.

Joint Report by Confederation of Indian Industries and Mc Kinsey and Company. FAIDA.

Mukherjee, K. N., (2011). Impact of Futures Trading on Indian Agricultural Commodity Market. Munich Personal RePEc Archive.

Narula, K., One Country One Myth. Centre for Civil Society.

No proof of commodity futures trading. Study by Reserve Bank of India.

Planning Commission Five Year Plan Report. www.planningcommission.nic.in

Prices stability and futures. Study by Kalyan Raipuria. Published in Economic and Political Weekly.

Sen, S. and Paul, M. (2010). Trading in India's Commodity Futures Market.

Srinivasan, S. (2008). Futures Trading in Agricultural Commodity. Centre for Civil Society.

To control food inflation agricultural commodities spared futures tax. Published in Hindustan Times.

Tomek, W.G. (1980). Price behavior on a declining terminal market. American Journal of Agricultural Economics.

U.P to promote futures trading in agricultural commodities. Article in Business Standard. 